\title{
Typification and taxonomic notes of Smilacaceae species in Java
}

\author{
Lulut Dwi Sulistyaningsih ${ }^{1 *}$, Abinawanto ${ }^{2}$, Marlina Ardiyani $^{1}$, Andi Salamah ${ }^{2}$, Agus Haryadi ${ }^{1}$ \\ ${ }^{1}$ Herbarium Bogoriense, Research Centre for Biology, Indonesian Institute of Sciences \\ Jl. Raya Jakarta-Bogor Km. 46, Bogor, Indonesia. 16911 \\ *Email: lulutjv@gmail.com \\ ${ }^{2}$ Department of Biology, Faculty of Mathematics and Natural Sciences, Universitas Indonesia \\ Kampus UI Gedung E Level 2, Jl. Lingkar Kampus Raya, Pondok Cina, Depok, West Java, Indonesia. 16424
}

\begin{abstract}
Smilacaceae is known as a taxa with wide phenotypic variation and their taxonomical complexities remain unsolved. The three species of Smilacaceae housed in Java, are given nomenclature history. Since all the potential sources of original material have been investigated, but nothing has been identified, three neotypifications were designated here. Herbarium specimen of Koorders $34990 \beta$ in Herbarium Bogoriense (BO) was chosen as the neotype of Smilax klotzschii. The de Groot \& Wehlburg RD52 herbarium specimen in BO was chosen as the neotype of S. nageliana and Blume 463 herbarium specimen in L was chosen as the neotype of S. odoratissima.
\end{abstract}

Keywords: Canar; Java; neotype; Smilax

Article History: Received 12 November 2020; Received in revised form 13 February 2021; Accepted 30 May 2021; Available online
30 June 2021
How to Cite This Article: Sulistyaningsih LD, Abinawanto A, Ardiyani M, Salamah A, Haryadi A. 2021. Typification and taxonomic
notes of Smilacaceae species in Java. Biogenesis: Jurnal Ilmiah Biologi. vol 9(1): 42-49. doi: https://doi.org/10.24252/bio.v9i1.17218.

\section{INTRODUCTION}

Smilacaceae was a family proposed by Ventenant in 1799 with Smilax L. as the genus type. This family consisted of more or less 200 climber species with tuberous or stoloniferous rhizomes, alternate leaves with reticulate venation. In addition, they had paired interpetiolar tendrils, mostly spinous stems, unisexual flowers with six tepals, and either six fertile stamens or staminodes in pistillate flowers, umbellate inflorescence, including fleshly berries. This family has a long nomenclature history and has been placed in various positions, such as in Liliales sensu lato (s.l.) (Hutchinson, 1979; Thorne, 1983; Goldberg, 1989; Cronquist, 1991), Dioscoreales (Dahlgren \& Clifford, 1982; Thorne, 1992) or Asparagales (Hurber, 1969). Takhtajan (1987) considered Smilacaceae as a member of Smilacales which included three additional families, namely: Philesiaceae (Philesia Comm. ex Juss., Lapogeria Ruiz \& Pav.), Ripogonaceae (Ripogonum J.R.Forst \& G.Forst), and Luzuriagaceae (Luzuriaga Ruiz \& Pav). Recent studies have confirmed that Smilacaceae is a member of a monophyletic Liliales, closely related to Philesiaceae, Ripogonaceae, and Liliaceae sensu stricto (s.s.) (Chase et al., 1995; Patterson \& Givnish, 2002;
Fay et al., 2006; Kim et al., 2013; Petersen et al., 2013).

Taxonomical and systematic study of Smilacaceae is still ongoing because the problems remain complex. Moreover, the concept of the genus, species, or infraspecific taxa delimitation is still unclear and doubtful. Recent floristic and monographic studies of Smilacaceae showed that only about 200 from more than 350 species already described are currently known in the family with more than 40\% considered synonyms (Qi et al., 2013). This is due to the taxonomic confusion about Smilacaceae. The species determination of Smilacaceae is challenging because they are dioecious plants with considerable phenotypic variation within populations and even among leaves of the same individual plant (Cameron \& $\mathrm{Fu}$, 2006). Moreover, many herbarium specimens lack flowers of both sexes or even single-sex flowers.

In Asia, taxonomic studies of Smilacaceae was performed in some regions such as Papua New Guinea (Ridley, 1916), Philippines (Merrill, 1918), Peninsular Malaysia (Ridley, 1924), Java and Kalimantan (Backer \& Bakhuizen v.d. Brink Jr., 1968; Ungson \& Sastrapradja, 1976; Sofiah \& Sulistyaningsih, 2019), Taiwan (Koyama, 1975), and China (Chen \& Koyama, 2000). Revision studies of 
the genus Smilax have been performed in Central America and the Caribbean (FerrufinoAcosta \& Greuter, 2010). Furthermore, Backer \& Bakhuizen v.d. Brink Jr. (1968) have made an enormous monograph, titled "Flora of Java." However, for the family Smilacaceae, there were unclear circumscriptions for each species including their typifications. The typification must be the starting point of any taxonomic study especially under challenging taxa such as Smilacaceae (Ferrufino-Acosta \& Greuter, 2010; Altınordu, 2015). During this systematic study of Smilacaceae in Java, several names remained untypified. Although typifications are still needed since stabilizing the names will facilitate their use.

\section{MATERIALS AND METHODS}

This study was based on examination of relevant literature and specimens deposited in Herbarium Bogoriense (BO), Singapore Herbarium (SING), and type specimens images deposited in the following herbaria: The Natural History Museum (BM), Royal Botanic Garden (K), Naturalis (L) \& Muséum National d'Histoire Naturelle $(\mathrm{P})$ retrieved from JSTOR. For selecting types, protologues were compared with original material (mostly herbarium material) and the most complete and informative specimens were selected (Turland et al., 2018). The new type designations were listed in alphabetical order and the names accepted as correct are in bold italic.

\section{RESULTS AND DISCUSSION}

\section{Smilax klotzschii Kunth}

Smilax klotzschii Kunth, Enum. Pl. (1850) 5: 245. - Type: Java, Djapara, 1899, Koorders $34990 \beta$ (Neotype, designated here, BO [1436082]) -Fig. 1.

Synonym: Smilax klotzschii var. angulosa A.DC.

Distribution - Smilax klotzschii only found in Central Java at the time of this study.

Notes - Smilax klotzschii is native to Java and distribution has been restricted around Central
Java. Kunth (1850) described these species in Enumeration Plantarum Omnium Hucusque Cognitarum, based on a single herbarium specimen collected from Java by Klotzsch in Herb. Reg. Berol. De Candolle (1878) in Monographiae Phanerogamarum cited Hoffmans 82 in Herb. DC and described a new variety of Smilax klotzschii, var. angulosa with Ploem no 17 in Herb. Kunth as holotype. All the original material cited above has not been traced. However, important Herbaria were known to house some of their duplicates such as $\mathrm{K}, \mathrm{L}, \mathrm{BO}, \mathrm{BM}, \mathrm{BR}$, US, P, and even the Geneva Herbarium (G). The Geneva Herbarium has the specimens used for the preparation of the "Podrome" (1824-1873) and its continuation the "Monographie Phanerogamarum" (1874-1896). This also included the Augustin Pyramus De Candolle collections of Smilacaceae. Since all potential sources of original material have been investigated, but nothing was found, a neotype was proposed here (Art. 9.7 of the International Code of Nomenclature, Turland et al., 2018). The selected specimen was in morphological agreement with the material studied since these specimen represented the species description in the protologue.

\section{Smilax nageliana A.DC}

Smilax nageliana A.DC. Monogr. Phan 1 (1878): 184 - Type: Java, Malang, Ranoe Daroengan, 19-22 Oct 1942, de Groot \& Wehlburg RD52 (Neotype, designated here, BO [1597624]) -Fig. 2.

Distribution - These species found in East Java.

Notes - Alphonso de Candolle described a single specimen, Nagel no 27 in Herbarium Berlin (B) Germany as a newly described species, Smilax nageliana. Since the Herbarium Berlin was destroyed during World War II, the holotype is most likely lost. After careful tracking and observation of herbarium specimens including digital specimens in herbaria such as BM, BO, BR, G, K, L, SING, and US, no potential sources of original 
material of Smilax nageliana was found. Since there is no original material still in existence or as long as it is missing, a neotype was proposed here (Art. 9.12, the International Code of Nomenclature, Turland et al., 2018). East java has restricted the distribution of Smilax nageliana. The Herbarium Bogoriense (BO) has just two specimen collection numbers, while de Groot \& Wehlburg RD52 specimen represents the protologue description.

\section{Smilax odoratissima Blume}

Smilax odoratissima Blume, Enum. Pl. Javae (1831) 19; Alphonso de Candolle in Monogr. Phan. 1 (1878) 196; Stapf in Trans. Linn. Soc. Bot. 4 (1894) 242. Type - Java, Blume 463 (Neotype, designated here, L [L1462698]). Fig. 3.

Distribution - It is native to Bangladesh, Borneo, Java, Lesser Sunda Island, Myanmar, and Thailand. These species are widespread in West Java, Central Java, and East Java.

Notes - Smilax odoratissima is distributed in the Malesia region, from Java to the Philippines. These species were first described by Blume (1831) in Enumeratio Plantarum Javae et insularum adjacentium without any specimen cited. Alphonso de Candolle (1878) in Monographiae Phanerogamarum cited five specimens as lectotypes (i.e. Blume s.n. in Herb. Lugd. Bat., Jaeger 367 et 464 in Herb. Ber., Nagel 28, Lobb s.n. in K, Zoll 505 in Herb. Boiss). There were some Smilax odoratissima specimens in Herb. Ludg. Bat in $\mathrm{L}$, but the Blume s.n. no longer exists. Similarly, Lobb s.n. was not found in K. Jaeger 367 was destroyed, while Zoll 505 in Herb. Boiss was not found at some herbaria such as BM, BO, BR, G, K, L, SING, and US. Since no original material linked to Smilax odoratissima could be traced, a neotype was proposed here (Art. 9.7, the International Code of Nomenclature, Turland et al., 2018). There were some Smilax odoratissima specimens of Herb. Lugd. Bat. in BO and L: Mousset 638 (Java, BO), CA Backer 5663 (Pengalengan, BO \& L), CA Backer 26146 (Pengalengan, 14 Oct 1918, BO \& L), Koorders $37654 \beta$ (Ngadisari, 9 Oct 1899, BO \& L), Koorders $28590 \beta$ (Pantjoer Idjen, 28 Aug 1897), Junghuhn 171 (Java, 1835-1863, L), and Blume 463 (Java, Mt Gede, L). Blume's collection was chosen as a neotype because one of the five specimens designated as lectotype by Alphonso de Candolle was a Blume specimen. Blume 463 represents the protologue description. 


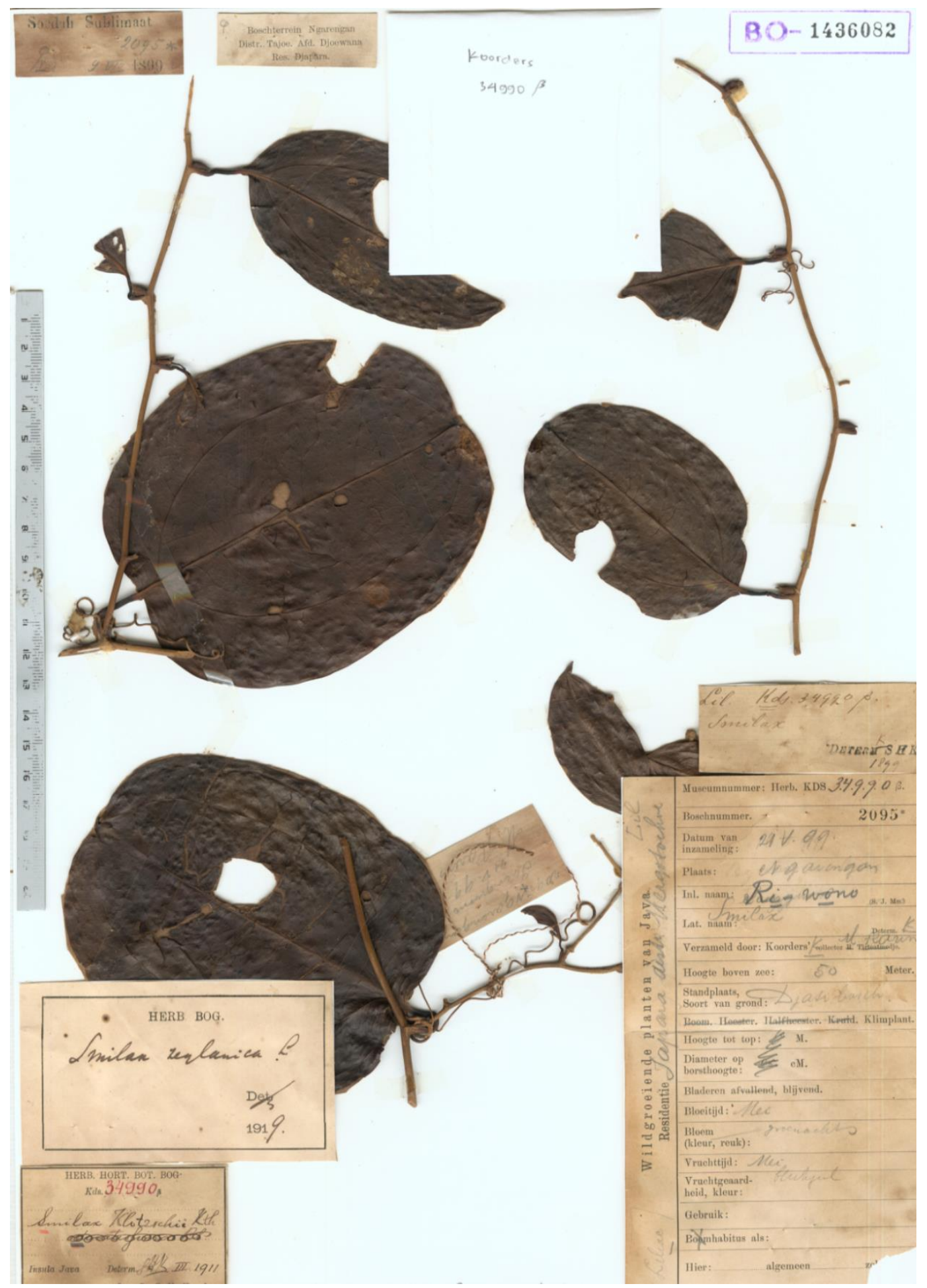

Fig. 1. Neotype of Smilax klotzschii Kunth, Koorders 34990ß (BO). 


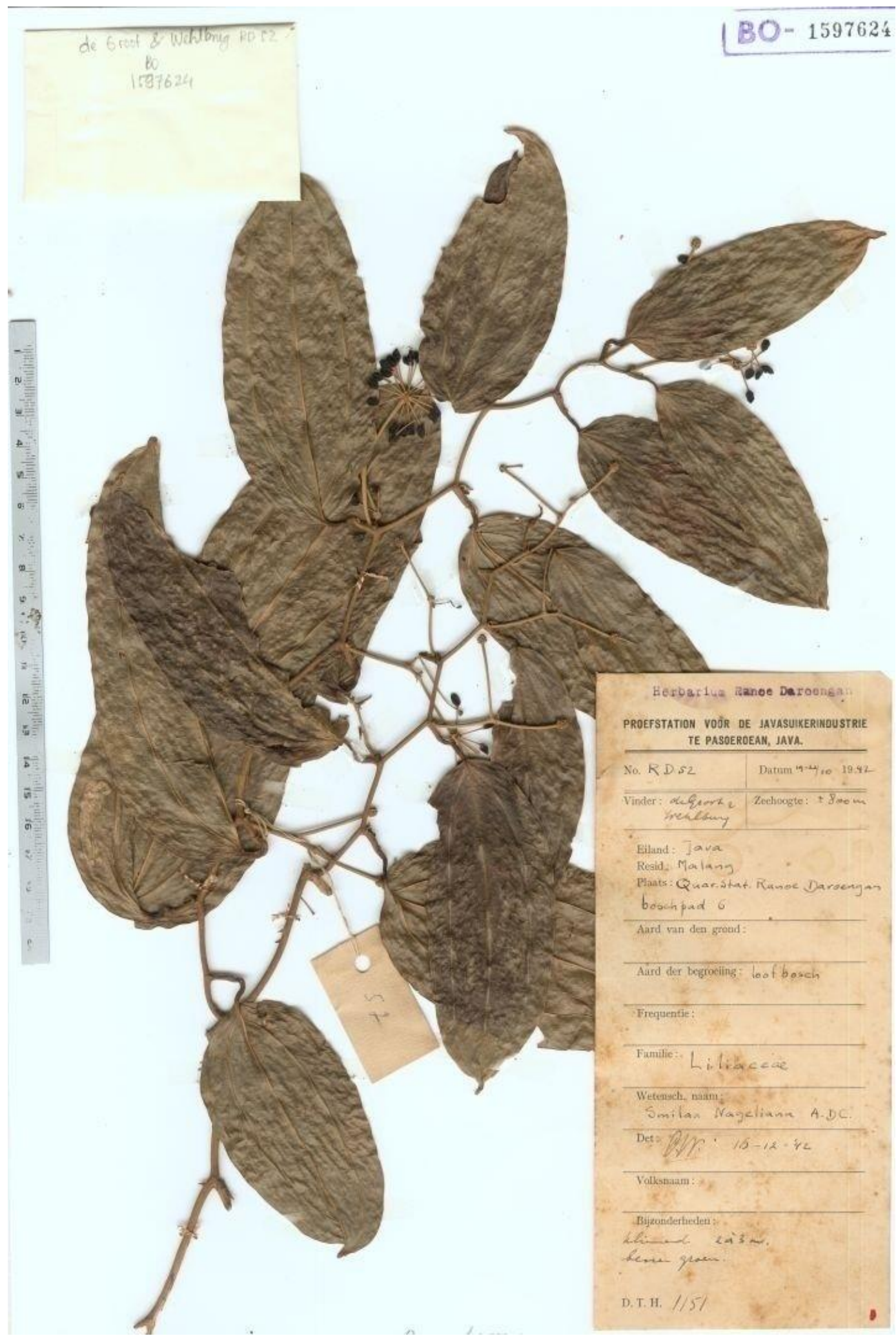

Fig. 2. Neotype of Smilax nageliana A.DC, de Groot \& Wehlburg RD52 (BO). 


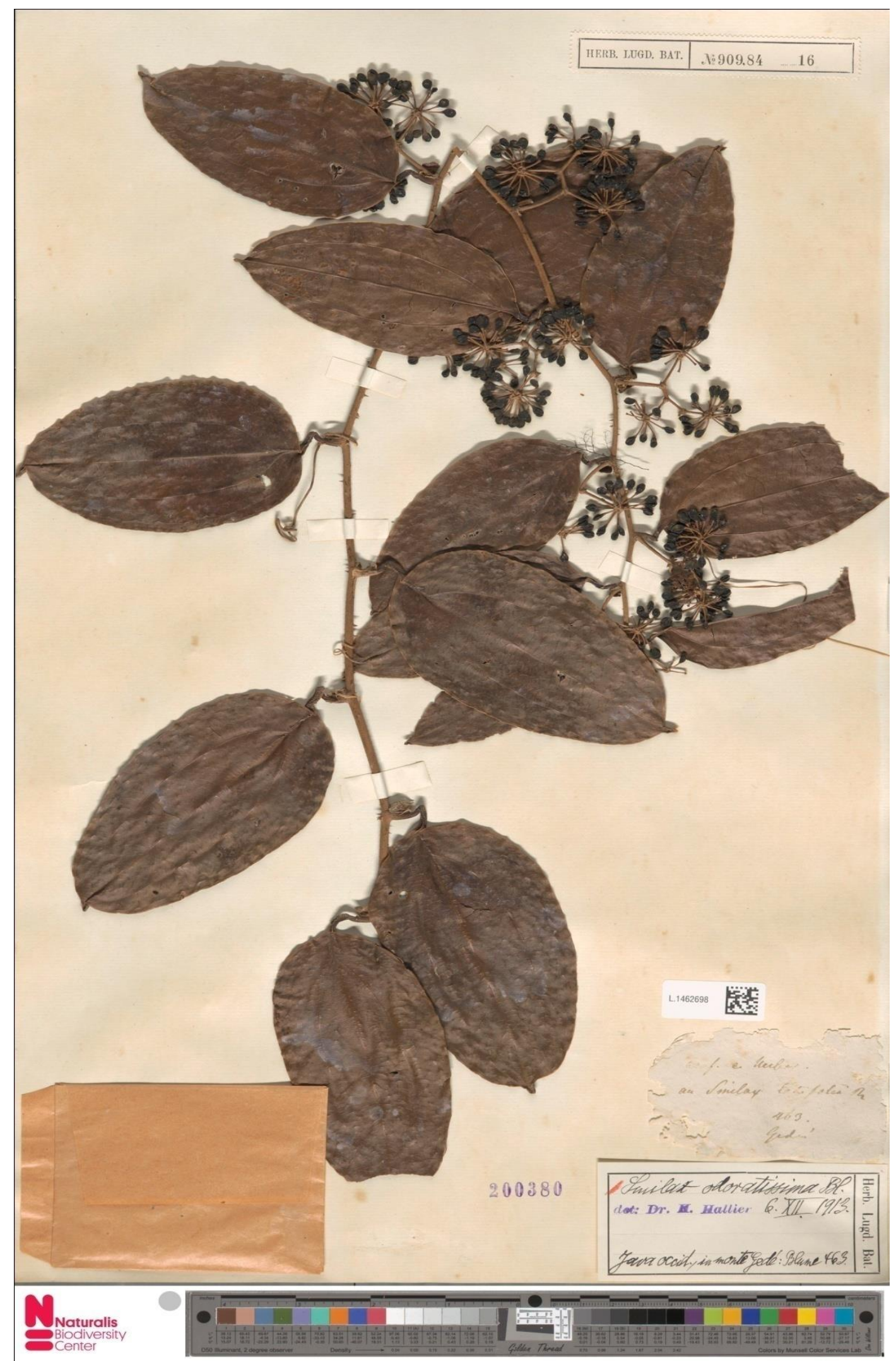

Fig. 3. Neotype of Smilax odoratissima Blume, Blume 463 (L). 


\section{CONCLUSION}

Three neotypification were made for the three species of Smilacaceae. Herbarium specimen of Koorders $34990 \beta$ was chosen as the neotype of Smilax klotzschii. The de Groot \& Wehlburg RD52 herbarium specimen was chosen as the neotype of $S$. nageliana, while Blume 463 herbarium specimen was chosen as the neotype of $S$. odoratissima.

\section{ACKNOWLEDGEMENTS}

The authors thank to Herbarium Bogoriense, Research Centre for Biology, Indonesian Institute of Sciences, as well as all participants to make this research came to reality.

\section{REFERENCES}

Altınordu F. 2015. Lectotypification of the Linnean name Smilax china (Smilacaceae). Phytotaxa. vol 234(2): 199-200.

doi: https://doi.org/10.11646/phytotaxa.234.2.12.

Backer CA, Bakhuisen van den Brink Jr RC. 1968. Flora of Java (Spermatophytes. Only). Vol. III WoltersNoordhoff, N.V. Groningen: P. Noordhoff. pp 3538.

Cameron KM, Fu C. 2006. A nuclear rDNA phylogeny of Smilax (Smilacaceae). Aliso. vol 22(1): 598-605. doi: https://doi.org/10.5642/aliso.20062201.47.

Chase MW, Stevenson DW, Wilkin P, Rudall PJ. 1995. Monocot systematics: a combined analysis. In: Rudall PJ, Cribb PJ, Cutler DF, Humphries CJ. (Eds). Monocotyledons: Systematics and Evolution. London: Kew Royal Botanic Gardens. pp 685-730.

Chen XQ, Koyama T. 2000. Smilax. In: Wu Z, Raven PH, Hong D, eds. Flora of China. Beijing and St Louis: Science Press and Missouri Botanical Garden Press. pp 96-117.

Cronquist A. 1991. The Evolution and classification of flowering plants. $2^{\text {nd }}$ ed. New York: New York Botanical Garden. p 555.

Dahlgren RMT, Clifford HT. 1982. The monocotyledons, a comparative study. London: Academic Press. p 378.

Fay MF, Chase MW, RØnsted N, Devey DS, Pillon Y. 2006. Phylogenetics of Liliales. Aliso. vol 22(1): 559-565.

Ferrufino-Acosta L, Greuter W. 2010. Typification of the name Smilax lenceolata L. Taxon. vol 59(1): 287 288. doi: http://dx.doi.org/10.1002/tax.591027.

Goldberg A. 1989. Classification, evolution, and phylogeny of the families of Monocotyledons. Washington, DC: Smithsonian Institution Press. p 74.

Hurber H. 1969. The treatment of monocotyledons in an evolutionary system of classification. Plant
Systematics and Evolution Supplement. vol 1: 285 298.

Hutchinson J. 1979. The families of flowering plants arranged according to a new system based on their probable phylogeny. $3^{\text {rd }}$ ed. Oxford: Clarendon Press. p 968.

Kim JS, Hong J-K, Chase MW, Fay MF, Kim JH. 2013. Familial relationship of the monocot order Liliales based on a molecular phylogenetic analysis using four plastid loci: matK, rbcL, atpB and atpF-H. Botanical Journal of the Linnean Society. vol 172(1): 5-21. doi: https://doi.org/10.1111/boj.12039.

Koyama T. 1975. Two new species of Smilax (Smilacaceae) from Taiwan. Taiwania. vol 20(2): 117-122. http://dx.doi.org/10.6165\%2ftai.1975.20.117.

Merrill ED. 1918. New or noteworthy Philippine plants XIII. The Philippine Journal of Science. vol 13: 166.

Patterson TB, Givnish TJ. 2002. Phylogeny, concerted convergence, and phylogenetic niche conservatism in the core Liliales: insights from $\mathrm{rbcL}$ and $\mathrm{ndhF}$ sequence data. Evolution. vol 56(2): 233-252. doi: https://doi.org/10.1111/j.00143820.2002.tb01334.x.

Petersen G, Seberg O, Davis JI. 2013. Phylogeny of the Liliales (Monocotyledons) with special emphasis on data partition congruence and RNA editing. Cladistics. vol 29(3): 274-295. doi: https://doi.org/10.1111/j.1096-0031.2012.00427.x.

Qi Z, Cameron KM, Li P, Zhao Y, Chen S, Chen G, Fu C. 2013. Phylogenetics, character evolution, and distribution patterns of the greenbriers, Smilacaceae (Liliales), a near-cosmopolitan family of monocots. Botanical Journal of the Linnean Society. vol 173(4): 535-548. doi: https://doi.org/10.1111/boj.12096.

Ridley HN. 1916. I. Report on the Botany of the Wollaston Expedition to Dutch New Guinea, 1912 13. Transactions of the Linnean Society of London. $2^{\text {nd }}$ Series. Botany. vol 9(1): 1-269. doi: https://doi.org/10.1111/j.10958339.1916.tb00009.x.

Ridley HN. 1924. The flora of the Malay Peninsula, Vol V. Monocotyledones, Gymnospermeae, General Indices. London: L. Reeve \& Co., Ltd. pp 4-233

Sofiah S, Sulistyaningsih LD. 2019. The diversity of Smilax (Smilacaceae) in Besiq-Bermai and Bontang Forests, East Kalimantan, Indonesia. Biodiversitas Journal of Biological Diversity. vol 20(1): 279 287. doi: https://doi.org/10.13057/biodiv/d200187.

Takhtajan A. 1987. Systema magnoliophytorum. Leningrad. Naukas: p 634.

Thorne RF. 1992. An update phylogenetic classification of the flowering plants. Aliso. vol 13: 365-389. doi: https://doi.org/10.5642/aliso.19921302.08.

Thorne RF. 1983. Proposed new realignments in the angiosperms. Nordic Journal of Botany. vol 3: 85117. doi: https://doi.org/10.1111/j.1756- 
1051.1983.tb01447.x.

Turland NJ, Wiersema JH, Barrie FR, Greuter W, Hawksworth DL, Herendeen PS, Knapp S, Kusber W-H, Li D-Z, Marhold K, May TW, McNeill J, Monro AM, Prado J, Price MJ, Smith GF (Eds). 2018. International Code of Nomenclature for Algae, Fungi, and Plants (Shenzhen Code) Adopted by the Nineteenth International Botanical Congress Shenzhen, China, July 2017. Regnum Vegetabile 159. Glashütten: Koeltz Botanical Books. p 254.

Ungson LB, Sastrapradja S. 1976. Variation in Smilax species (Sarsaparilla) of Java (Indonesia). Biotrop Bulletin. vol 12: 1-24. 